\title{
Bifidogenic effect of salep powder
}

\section{Salep tozunun bifidojenik etkisi}

\author{
Buse USTA GORGUN ${ }^{1}$ iD, Lutfiye YILMAZ ERSAN ${ }^{* 2}$ iD \\ ${ }^{1}$ Uludag University, Faculty of Agriculture, Institute of Natural Sciences, Bursa-Turkey \\ ${ }^{2}$ Uludag University, Faculty of Agriculture, Department of Food Engineering, Bursa-Turkey
}

\section{To cite this article:}

Usta Gorgun, B. \& Yılmaz Ersan, L. (2019). bifidogenic effect of salep powder. Harran Tarım ve Gıda Bilimleri Dergisi, 23(2): 150158. DOI: 10.29050 /harranziraat.444569

Address for Correspondence: Lutfiye YILMAZ-ERSAN

e-mail:

lutfiyey@uludag.edu.tr

Received Date:

17.07.2018

Accepted Date:

26.10.2018

(C) Copyright 2018 by Harran University Faculty of Agriculture. Available on-line at www.dergipark.gov.tr/harranziraat

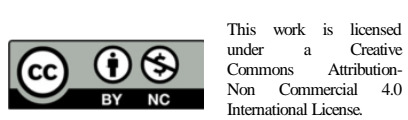

\section{ABSTRACT}

The aim of this research was to study the bifidogenic effect of salep powder on some Bifidobacterium species, namely B. lactis, $B$. infantis, $B$. longum and B. bifidum. The growth of the Bifidobacterium species was investigated by measuring the $\mathrm{pH}$ and optical density (OD) during $48 \mathrm{~h}$-fermentation. In order to evaluate the efficiency of the fermentation of salep powder by the Bifidobacterium subsp. lactic, acetic, butyric and propionic acid values in the growth media were quantified by HPLC. It was determined that Bifidobacterium species might be used salep powder as a source of carbon and the highest OD values were found for $B$. lactis in media containing glucose and for $B$. infantis in media containing salep powder. All the tested strains observed the ability to produce higher amounts of lactic and acetic acids than amounts of propionic and butyric acids. Consequently, it was determined that all four Bifidobacterium species were able to ferment salep powder. Moreover, because salep powder enhanced the growth and activity of Bifidobacteria and it might be conferred as a bifidogenic effect.

Key Words: Bifidobacterium, Bifidogenic effect, Salep powder

\section{Öz}

$\mathrm{Bu}$ araştırmanın amacl, salep tozunun $B$. lactis, $B$. infantis, $B$. longum ve $B$. bifidum'u içeren bazı Bifidobacterium türleri üzerine bifidojenik etkisini araştırmaktır. Bifidobacterium türlerinin gelişmesi, 48 saatlik fermantasyon süresince $\mathrm{pH}$ ve optik yoğunluk (OD) ölçülerek incelenmiştir. Bifidobacterium türleri tarafından salep tozunun fermantasyonunun etkinliğini değerlendirmek amacıyla gelişme ortamındaki laktik, asetik, bütirik ve propiyonik asit değerleri HPLC cihazı kullanılarak saptanmıştır. Bifidobacterium türlerinin karbon kaynağı olarak salep tozunu kullanabildiği ve glikoz içeren ortamda $B$. lactis ve salep tozu içeren ortamda $B$. infantis için en yüksek OD değerleri gözlenmiştir. Test edilen tüm suşların, propiyonik ve bütirik asit miktarlarından daha yüksek oranda laktik ve asetik asit üretebildiği belirlenmiştir. Sonuç olarak, dört Bifidobacterium türünün salep tozunu fermente edebildiği gözlenmiştir. Ayrıca, salep tozu Bifidobacterium türlerinin gelişmesini ve aktivitesini artırdığı için bifidojenik etkili olarak kabul edilebilir.

Anahtar Kelimeler: Bifidobacterium, Bifidojenik etki, Salep tozu

\section{Introduction}

There is growing interest in functional foods having beneficial effects on the human health. Probiotics, prebiotics and synbiotics have gained an important to modulate the gut microbiota with the aim of improving host health. Probiotics have been defined by WHO and FAO as "viable nonpathogenic microorganisms which, when administered in adequate amounts, demonstrate beneficial effect on the human health". The beneficial effects of the probiotics are inhibition the growth of the intestinal pathogens, improved lactose digestion, enhancing the immune system, 
lowering the risk of cancer, treatment and prevention of obesity, diabete, cardiovascular diseases and some allergic reactions. Although there are hundreds of probiotic species such as Bifidobacterium, Lactobacillus, Lactococcus, Saccharomyces, and Enterococcus. Bifidobacterium and Lactobacillus species are most commonly used probiotic species in food products (Bernardeau et al., 2008; Pan et al., 2009; Shokryazdan et al., 2017; Kerry et al., 2018; Zoumpopoulou et al., 2018).

Bifidobacterium species are gram-positive, high guanine+cytosine, catalase negative, rod-shaped, non-immobile, non-sporulate, obligate anaerobes with the exceptions of a few species, highly sensitive to $\mathrm{pH}$ above 8.0 or below 4.5 with optimum growth between 37 to $41^{\circ} \mathrm{C}$. B. breve, $B$. bifidum, $B$. adolescentis, $B$. animalis, $B$. infantis, $B$. lactis and $B$. longum are the most recognized species of Bifidobacteria used as probiotics. Bifidobacterium species consumed at adequate levels have demonstrated beneficial effects on treatment and/or prevention of some diseases namely concerning immune system, gastrointestinal infections, hypertension, cholesterol and cancer. Bifidobacteria constitute $95 \%$ of the total intestinal microbiota in the colons of breastfed infants and decline with age and changes in eating habits (Champagne et al., 2005). Many attempts have been made to stimulate the growth of bifidobacteria and to increase their populations in the intestines of humans and/or animals and a food by supplying biologically active components called as "bifidogenic factor" or "bifidus factor" (Wang et al., 2010; GonzálezRodríguez et al., 2013). Bifidogenic factor was described by Modler (1994) and Gomes and Malcata (1999) as a carbohydrate that survive direct metabolism by the host and reach the colon where they are preferentially metabolised by Bifidobacteria as source of energy. Recently, this factor is called as a prebiotic. Prebiotics are non-digested, not-hydrolyzed and non-absorbed food ingredients in stomach and small intestine. They have been fermented by the gut microbiota that causes specific changes, both in the composition and/or activity in the gastrointestinal microbiota. As a result of fermentation, a) potentially health promoting metabolites such as lactic acid, short chain fatty acids, bacteriocins and $B$ vitamins are formed, $b$ ) the colonic flora by exerting bifidogenic effect (the proliferation of bifidobacteria) have been modulated and c) the growth of undesirable bacteria has been inhibited. Thus, prebiotics have demonstrated health benefits including detoxification of toxic substances, reduction of blood ammonia levels and cholesterol, stimulation of mineral uptake and the treatment/prevention of cancer and infectious diseases (Bindels et al., 2015; Shigwedha et al., 2016; Carlson et al., 2018).

Cereals, legume crops, vegetables (chicory, onions, leek, artichoke etc.), fruits (dragon fruit, jack fruit etc.) and milk components (oligosaccharides) are natural sources for prebiotics. However, inulin, fructooligosaccharides, oligofructose, (trans-) galactooligosaccharides (TOS or GOS) or lactulose derived through biochemical and/or enzymatic techniques from these foods are the most used prebiotics at production of industrial products (Gibson and Rastall, 2006; Wang et al., 2010; RiosCovian et al., 2013; Sousa et al., 2015; Underwood et al., 2015).

Synbiotic has been called as combining probiotic bacteria with prebiotics. In a synbiotic composition, prebiotics should be fermented selectively by the probiotic strain. Fermentation of the prebiotic results in a) increasing of beneficial microbiota (e.g., bifidobacteria and lactobacilli), b) decreasing the populations of potentially pathogenic microbiota (e.g., Clostridium perfringens and E. coli), c) lowering of the $\mathrm{pH}$ and $\mathrm{d}$ ) production of short-chain fatty acids (SCFAs), mainly acetic, propionic and butyric acids. SCFAs might serve health promoting properties such as promoting the absorption of water and minerals including calcium, magnesium and iron, inhibiting cholesterol synthesis and the prevention/treatment of the metabolic syndrome, bowel disorders and certain types of cancer (Morrison and Preston, 2016; 
Markowiak and Śliżewska, 2017; McNabney and Henagan, 2017).

Orchids are mostly cultivated as beautiful flowers which have immense economic importance and medicinal value. The salep powder is obtained from grinding dried tubers of Orchis mascula, Orchis militaris and related species of orchids growing naturally in Turkey. Salep is used as very nutritive ingredient in a delicious hot drink known by the same name, traditional Kahramanmaras-type of ice cream, soft drinks and confectionary industries. In traditional medicine, salep is used as an aphrodisiac in sexual activity and erectile dysfunction, as a blood sugar manager to relieve pancreas stress, in the prevention of chronic disorders, in treatment of bowel disorders, tuberculosis, diarrhea, Parkinson's, cancer, fever and weight management (Jagdale et al., 2009; Altundag et al., 2012; Pourahmad, 2015; Jahromi et al., 2018). Although the components of salep vary according to the season of collection and orchid species, generally it contains mucilage (48\%), moisture (12\%), sugar (1\%), starch (3\%), nitrogenous substance (5\%), ash (2\%) and glucomannan (16\%-60\%). Glucomannan is a natural neutral water-soluble fiber which is important in normalizing blood sugar, relieving stress on the pancreas and preventing blood sugar abnormalities, such as hypoglycemia (Staiano et al., 2000; Keithley and Swanson, 2005; Onakpoya et al., 2014; Tester and Al-Ghazzewi, 2017).

Recently, researchers have studied to find innovative or alternative sources which are commercially available prebiotics. In this context, prebiotic properties of glucomannan have been reported by many researches (Connolly et al., 2010; Muller et al., 2012; Harmayani et al., 2014). Salep powder may be metabolized by bifidobacteria and demonstrate bifidogenic as well prebiotic effect, probably due to its glucomannan content.

In order to develop candidate prebiotic substrates, firstly the bacterial fermentation properties of a substrate can be initially determined using in vitro models and its prebiotic activity can later be confirmed by controlled human clinical trials. The objective of this research was to determine the fermentability of salep powder by some bifidobacteria species. Glucose, a non-prebiotic simple carbon source, is able to metabolized by probiotic fastly and reach maximum growth more quickly, thus it was chosen as a positive control. The comparison was made in both basal media with salep powder and glucose as well as glucose. The growth of bifidobacteria species was tested by determining the optical density (OD) and $\mathrm{pH}$ values. In order to examine the biochemical activities of the species, high performance liquid chromatography (HPLC) analysis of lactic acid and short chain fatty acids (acetic, propionic and butyric acids) concentrations was also carried out.

\section{Materials and Methods}

\section{Bacterial strains}

The bacteria used in this study were Bifidobacterium longum subsp. infantis, Bifidobacterium animalis subsp. lactis, Bifidobacterium longum subsp. longum and Bifidobacterium bifidum. These strains were obtained from DSMZ (Deutsche Sammlung von Mikroorganismen und Zellkulturen $\mathrm{GmbH}$, Braunschweig, Germany). These strains were activated according to the method suggested by DSMZ and incubated at $37^{\circ} \mathrm{C}$ using an anaerobic atmosphere generation system (Anaerocult A, Merck, Darmstadt, Germany).

\section{Salep sample}

Salep from orchids grown different parts of Turkey region was provided by Kadem Sahlepcilik (Istanbul, Turkey). Stock solutions of salep were prepared in distilled water and filter-sterilized using Millipore-Stericup-GP $0.45 \mu \mathrm{m}$ (Kaplan and Hutkins, 2000; Mumcu and Temiz, 2014).

\section{Growth conditions}

Tryptone Peptone Yeast Extract (TPY) was used as the basal medium containing peptone 
$\left(5.00 \mathrm{~g} \mathrm{l}^{-1}\right)$, yeast extract $\left(2.50 \mathrm{~g} \mathrm{I}^{-1}\right)$, glucose $\left(5.00 \mathrm{~g} \mathrm{l}^{-1}\right)$, tween $80\left(1.00 \mathrm{~g} \mathrm{l}^{-1}\right), \mathrm{K}_{2} \mathrm{HPO}_{4} \cdot 3 \mathrm{H}_{2} \mathrm{O}$ $\left(2.00 \mathrm{gl}^{-1}\right), \mathrm{MgCl}_{2}\left(0.50 \mathrm{~g} \mathrm{I}^{-1}\right), \mathrm{ZnSO}_{4} .7 \mathrm{H}_{2} \mathrm{O}\left(0.20 \mathrm{~g} \mathrm{I}^{-}\right.$ $\left.{ }^{1}\right), \mathrm{CaCl}_{2}\left(0.15 \mathrm{~g} \mathrm{l}^{-1}\right), \mathrm{FeCl}_{3} \cdot 6 \mathrm{H}_{2} \mathrm{O}\left(0.003 \mathrm{~g} \mathrm{l}^{-1}\right)$ and L-cysteine $\mathrm{HCl}\left(0.50 \mathrm{~g} \mathrm{I}^{-1}\right)$. The medium was sterilised at $121^{\circ} \mathrm{C}$ for $15 \mathrm{~min}$. Sterile salep solutions were added into the basal TPY medium to obtain final concentrations of $0.5 \%(w / v$.) As positive control TPY with $0.5 \%(\mathrm{w} / \mathrm{v})$ glucose was used. The assay was performed by adding $2 \%$ $(w / v)$ of an overnight culture of Bifidobacterium subsp.

\section{pH measurement}

The $\mathrm{pH}$ of each sample was determined during fermentation using a $\mathrm{pH}-$ meter $(\mathrm{pH} 315 \mathrm{i} / \mathrm{SET}$; WTW, Germany).

\section{Growth measurement}

The optical density as cell density of bacteria was determined at $600 \mathrm{~nm}\left(\mathrm{OD}_{600}\right)$ with a spectrophotometer (Shimadzu UV 1800, Kyoto, Japan) during fermentation. The corresponding sterile TPY solutions without bacteria were used as blanks for the absorbance measurements.

\section{Lactic acid and SCFA analyses}

To evaluate the efficiency of the fermentation of salep by the Bifidobacterium subsp., HPLC was performed. Lactic, acetic, butyric and propionic acids can be detected in the growth medium and quantified by HPLC (Shimadzu marka LC-20 AD, Japan, [17]. The HPLC equipment consisted of Transgenomics ORH-801 column and Refractive Index Detectors (RID) (Shimadzu, Kyoto, Japan) connected to a recorder. Samples were filtered through a $0.45 \mu \mathrm{m}$ syringe filter prior to injection into the HPLC column. The injection volume was $20 \mu \mathrm{l}, 0.0025 \mathrm{~N} \mathrm{H}_{2} \mathrm{SO}_{4}$ was used as the mobile phase, under a flow rate of $0.6 \mathrm{~mL} \mathrm{~min}-1$ at $65{ }^{\circ} \mathrm{C}$ (Anonymous, 2012).

\section{Statistical analysis}

All results were expressed as mean \pm SD. Data was analyzed by two-way analysis of variance (ANOVA). Duncan's Multiple Range Test was applied to determine the significant difference between the fermentation times and substrates used as carbohydrate source at $P \leq 0.01$.

\section{Results and Discussion}

In order to determine the carbohydrate preferences of Bifidobacterium species, the optical density (OD) and $\mathrm{pH}$ were determined. Table 1 shows OD and $\mathrm{pH}$ values after the five fermentation times $(0,12,24,36$ and 48 hours) in anaerobic culture following supplementation with glucose as a positive control and salep powder (test substrate).

The results were presented as the mean value of each fermentation time (FT), regardless of the Bifidobacterium species (BS), and the mean value of each strain, regardless of the fermentation time. For all parameters, the interaction among both factors (BSxFT) could be determined, and for all parameters and every time, a significant interaction was detected $(P<0.01)$. Regarding the fermentation time, the highest value of optical density was recorded for media with glucose, while it showed $\mathrm{pH}$ value. In glucose samples, the $\mathrm{pH}$ decreased significantly $(P<0.01)$ during $48 \mathrm{~h}$ of fermentation. It was found that $\mathrm{pH}$ value for salep powder samples showed a temporal increase and decrease between $36 \mathrm{~h}$ and $48 \mathrm{~h}$. B. infantis has the lowest $\mathrm{pH}$ values in both media with glucose (4.52) and salep powder (5.25).

As shown in Table 1, Bifidobacterium species used salep powder as a source of carbon and energy. All strains grew well on glucose, the highest $O D$ values were found for the strains $B$. lactis in media containing glucose (1.114) and $B$. infantis in media containing salep powder (0.952). Optical density value when salep powder for $B$. infantis was used as a single carbon source was able to generate similar growth as that promoted by glucose (the traditional carbon source). Wang et al. (2010) reported that B. adolescentis displayed the highest growth on xylooligosaccharides with the maximum OD of 1.68 and the lowest $\mathrm{pH}$ value of 5.1, followed by $B$. longum and B. bifidum, however, B. breve did 
not show any growth on XOS. García-Cayuela et al. (2014) determined that the OD values after 48 h growth of $B$. lactis $\mathrm{BB}-12, B$. breve $26 \mathrm{M} 2$ and $B$. bifidum HDD541 with the six carbohydrates (glucose, lactulose, lactosucrose, kojibiose, lactulosucrose and 40-galactosyl-kojibiose) used as carbon sources ranged from 0 to 1.21 . On the other hand, the maximum OD for glucose values were obtained at $48 \mathrm{~h}$ of fermentation, while at $36 \mathrm{~h}$ of fermentation for salep powder. Voragen (1998) reported that chemical structure, degrees of polymerization (DP), composition of monomer units and water solubility of substrate affect their utilisation by probiotic microorganisms.

Table 1 The mean values of OD and pH values obtained by four Bifidobacterium species grown on glucose and salep powder for $48 \mathrm{~h}$

Çizelge 1 Glikoz ve salep tozu içeren ortamda dört Bifidobacterium türünün 48 saat fermantasyonu sonucunda elde edilen OD ve $\mathrm{pH}$ değerlerinin ortalama değerleri

\begin{tabular}{|c|c|c|c|c|c|}
\hline \multirow{2}{*}{$\begin{array}{l}\text { Bifidobacterium strains } \\
\text { (Bifidobacterium türleri) }\end{array}$} & \multirow[t]{2}{*}{$\mathrm{N}$} & \multicolumn{2}{|c|}{ OD (Optik yoğunluk) } & \multicolumn{2}{|c|}{$\mathrm{pH}$} \\
\hline & & $\begin{array}{l}\text { Glucose } \\
\text { (Glikoz) }\end{array}$ & $\begin{array}{l}\text { Salep powder } \\
\text { (Salep tozu) }\end{array}$ & $\begin{array}{l}\text { Glucose } \\
\text { (Glikoz) }\end{array}$ & $\begin{array}{l}\text { Salep powder } \\
\text { (Salep tozu) }\end{array}$ \\
\hline B. bifidum & 10 & $0.901^{\mathrm{BCa}}$ & $0.682^{\mathrm{Bb}}$ & $4.70^{\mathrm{cb}}$ & $5.52^{\mathrm{Ba}}$ \\
\hline B. infantis & 10 & $0.951^{\mathrm{ABa}}$ & $0.952^{\mathrm{Aa}}$ & $4.52^{\mathrm{Db}}$ & $5.25^{\mathrm{Ca}}$ \\
\hline B. lactis & 10 & $1.114^{\mathrm{Aa}}$ & $0.645^{\mathrm{Bb}}$ & $4.89^{B b}$ & $5.55^{\mathrm{Ba}}$ \\
\hline B. longum & 10 & $0.703^{\mathrm{Ca}}$ & $0.619^{\mathrm{Bb}}$ & $5.39^{\mathrm{bA}}$ & $5.90^{\mathrm{Aa}}$ \\
\hline \multicolumn{6}{|l|}{ Fermentation time (hours) } \\
\hline 0 & 8 & $0.077^{\mathrm{Ca}}$ & $0.113^{\mathrm{Da}}$ & $6.43^{\mathrm{Aa}}$ & $6.32^{\mathrm{Aa}}$ \\
\hline 12 & 8 & $0.831^{\mathrm{Ba}}$ & $0.608^{\mathrm{Ca}}$ & $5.12^{\mathrm{Ba}}$ & $5.69^{\mathrm{Ba}}$ \\
\hline 24 & 8 & $1.152^{\mathrm{Aa}}$ & $0.874^{\mathrm{Bb}}$ & $4.46^{\mathrm{cb}}$ & $5.35^{\mathrm{Ca}}$ \\
\hline 36 & 8 & $1.194^{\mathrm{Aa}}$ & $1.092^{\mathrm{Aa}}$ & $4.20^{\mathrm{Db}}$ & $5.17^{\mathrm{Da}}$ \\
\hline 48 & 8 & $1.334^{\mathrm{Aa}}$ & $0.935^{\mathrm{Ba}}$ & $4.16^{\mathrm{Db}}$ & $5.25^{\mathrm{CDa}}$ \\
\hline \multicolumn{6}{|l|}{ ANOVA } \\
\hline Bifidobacterium strains (BS) & & $* *$ & $* *$ & $* *$ & $* *$ \\
\hline Fermentation time (FT) & & $* *$ & $* *$ & $* *$ & $* *$ \\
\hline BSXFT & & $* *$ & $* *$ & $* *$ & $* *$ \\
\hline
\end{tabular}

A-D Different uppercase supercripts in the same column depict the significant difference between means for fermentation time and Bifidobacterium strains $(P<0.01)$

${ }^{a-d}$ Different lowercase supercripts in the same row depict the significant difference between glucose and salep powder $(P<0.01)$

\section{Lactic acid}

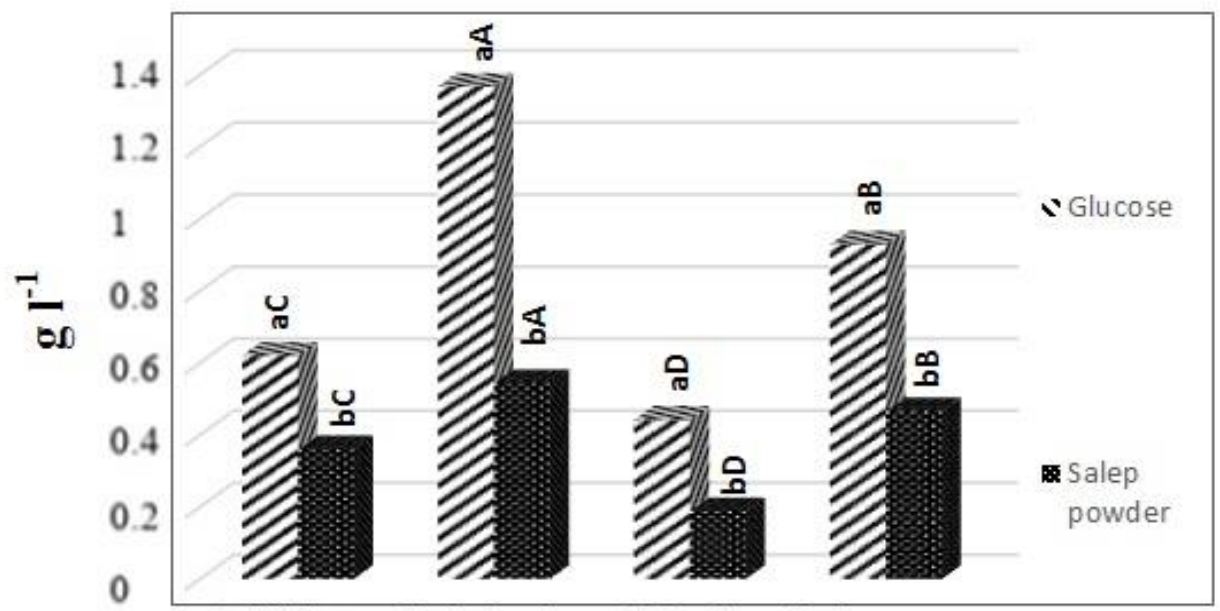
B. bifidum
B. infantis
B. lactis
B. longum

\section{Bifidobacterium subsp.}

Figure 1. Changes of lactic acid values of samples after the $48 \mathrm{~h}$-fermentation Şekil 1. 48 saatlik fermantasyon sonunda örneklerdeki laktik asit miktarındaki değişim

${ }^{a-d}$ Different lowercase supercripts depict the significant difference among samples $(P<0.01)$;

${ }^{A-D}$ Different uppercase supercripts depict the significant difference between Bifidobacterium subsp. $(P<0.01)$ 
Lactic acid is the main end-product of the glycolytic fermentation produced by lactic acid bacteria. For all the tested strains, lactic acid was the most abundant produced metabolite, this finding is in agreement with LAB metabolism. Figure 1 showed the lactic acid concentrations of Bifidobacterium species in media including glucose and salep powder. The concentration of lactic acid ranged from $0.19 \mathrm{~g} \mathrm{I}^{-1}$ of $B$. lactis in media with salep powder to the $1.37 \mathrm{~g} \mathrm{I}^{-1}$ of $B$. infantis in media with glucose, depending on the strain and type of subtrate. More lactic acid was produced from glucose than salep powder. $B$. infantis produced the higher lactic acid in media with salep powder than other species. Barczynska et al. (2012) reported that lactic acid content determined $109.3 \mathrm{mg} 100 \mathrm{~mL}^{-1}$ for B. bifidum

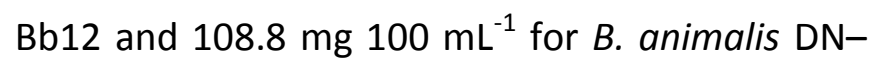

173010 in the broth containing the tartaric aciddextrin as the only one source of carbon after 24$h$ incubation.

\section{Short chain fatty acids}

Short-chain fatty acids (SCFAs) such as acetic, propionic and butyric acids are produced as the end products of the microbial fermentation of dietary carbohydrates via Bifidobacteria and Lactobacilli. The type number and enzymatic capabilities of microorganisms and substrate sources have affected amount and type of these metabolites' in vitro media (Wong et al., 2006). Also, in human body endogenous colonic microbiota like probiotic bacteria and gut transit time have affected production (Barczyńska et al., 2015; Pessione et al., 2015).

\section{Acetic acid}

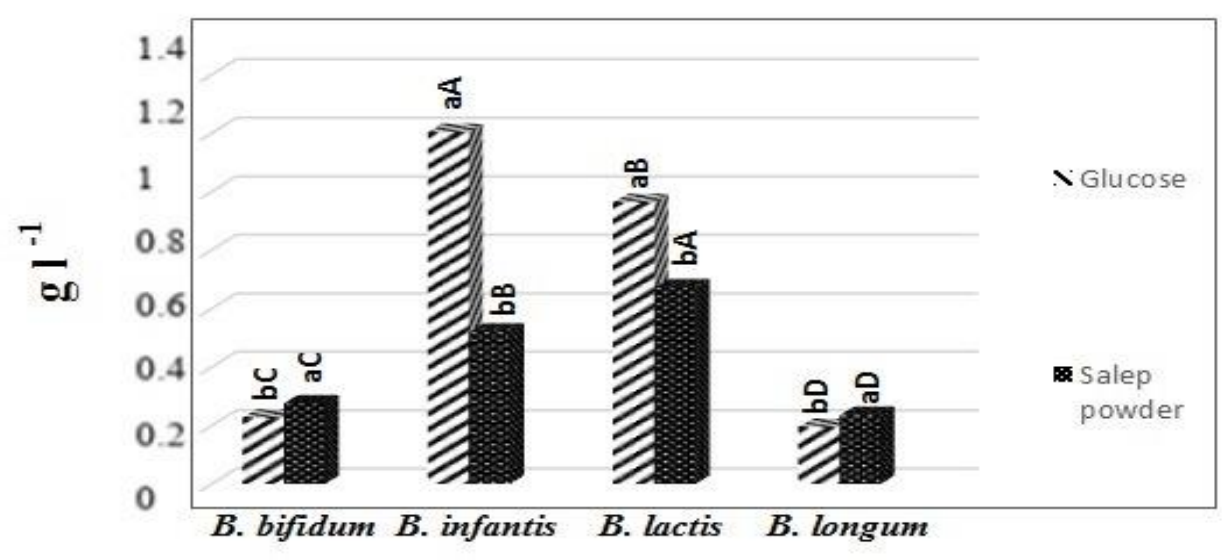

Bifidobacterium subsp.

Figure 2. Changes of acetic acid values of samples after the $48 \mathrm{~h}$-fermentation Şekil 2. 48 saatlik fermantasyon sonucunda örneklerdeki asetik asit miktarındaki değişim

${ }^{a-d}$ Different lowercase supercripts depict the significant difference among samples $(P<0.01)$;

${ }^{A-D}$ Different uppercase supercripts depict the significant difference between Bifidobacterium subsp. $(P<0.01)$

Acetic acid, the most abundant SCFA produced by the human colonic microbiota, can be used as energetic substrate in muscle tissue, controlling inflammation and counteracting pathogen invasion (Fukuda et al., 2011). The acetic acid concentrations of Bifidobacterium species were shown in Figure 2. Its concentration depended on the strain and substrate type. Acetic acid, it ranged from $0.19 \mathrm{~g} \mathrm{I}^{-1}$ of $B$. longum to $1.20 \mathrm{~g} \mathrm{l}^{-1}$ of $B$. infantis in media with glucose. The higher acetic acid values were observed for $B$. bifidum and $B$. longum in media with salep powder than glucose. Generally, during the whole fermentation progress, samples including salep powder exhibited a lower acetic acid value than glucose. It was found that acetic acid content determined $19.1 \mathrm{mg} 100 \mathrm{~mL}^{-1}$ for $B$. bifidum $\mathrm{Bb} 12$ and $16.9 \mathrm{mg} 100 \mathrm{~mL}^{-1}$ for $B$. animalis DN-173 010 in the broth containing the tartaric acid-dextrin as the only one source of carbon after 24-h incubation (Barczynska et al., 2012).

Propionic acid produced by certain colon bacteria can be transported to many parts of the 
body and utilized in liver cells (Hongpattarakere et al., 2012). It could be observed (Figure 3) that the fermentation time might influence the propionic acid values of Bifidobacterium species fermented in media including glucose and salep powder. Propionic acid contents ranged from $0.01 \mathrm{~g} \mathrm{l}^{-1}$ of $B$. longum to $0.13 \mathrm{~g} \mathrm{I}^{-1}$ of $B$. lactis in media with salep powder. For Bifidobacterium species, the maximum propionic acid value of $B$. lactis fermented in media with salep powder was observed. Barczynska et al. (2012) reported that propionic acid content determined $4.5 \mathrm{mg} 100$ $\mathrm{mL}^{-1}$ for B. bifidum $\mathrm{Bb} 12$ and $4.6 \mathrm{mg} 100 \mathrm{~mL}^{-1}$ for $B$. animalis $\mathrm{DN}-173010$ in the broth containing the tartaric acid-dextrin as the only one source of carbon after 24-h incubation.

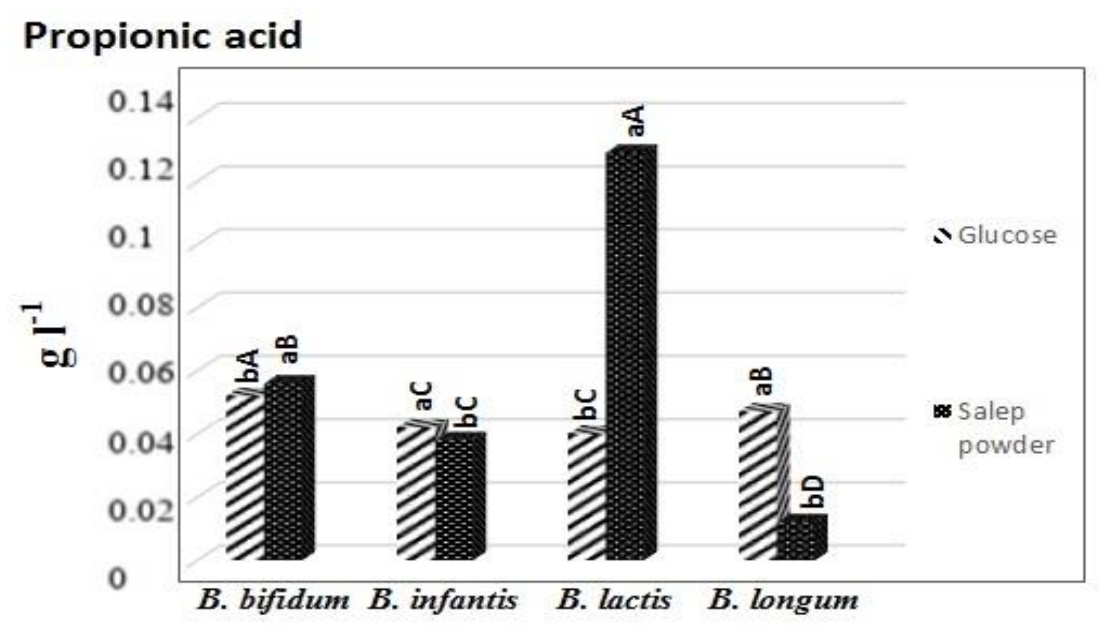

Bifidobacterium subsp.

Figure 3. Changes of propionic acid values of samples after the $48 \mathrm{~h}$-fermentation Şekil 3. 48 saatlik fermantasyon sonucunda örneklerdeki propiyonik asit miktarındaki değişim

${ }^{a-d}$ Different lowercase supercripts depict the significant difference among samples $(P<0.01)$;

${ }^{A-D}$ Different uppercase supercripts depict the significant difference between Bifidobacterium subsp. $(P<0.01)$

\section{Butyric acid}

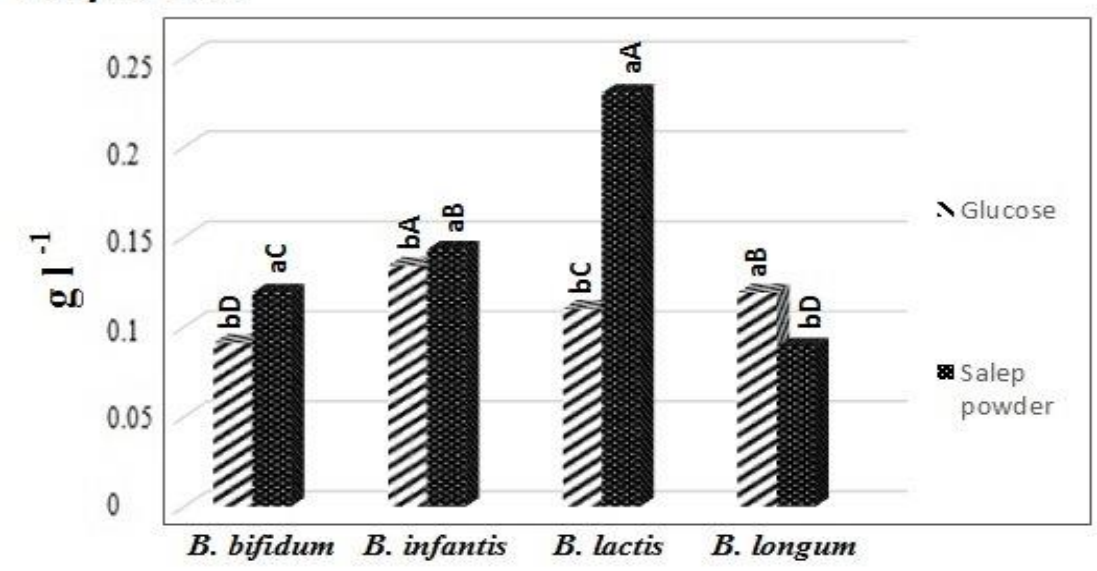

Bifidobacterium subsp.

Figure 4. Changes of butyric acid values of samples after the $48 \mathrm{~h}$-fermentation Şekil 4. 48 saatlik fermantasyon sonucunda örneklerdeki butirik asit miktarındaki değişim ${ }^{a-d}$ Different lowercase supercripts depict the significant difference among samples $(P<0.01)$;

${ }^{A-D}$ Different uppercase supercripts depict the significant difference between Bifidobacterium subsp. $(P<0.01)$

Butyric acid among SCFAs displays beneficial health effects such as the prevention and treatment of colonic diseases (Fung et al., 2012; Pessione et al., 2015). The Bifidobacterium species and type of substrate affected the butyric acid values. Generally, higher butyric acid values were present in media with salep powder. A maximum butyric acid value of $B$. lactis fermented in media with salep powder was observed, while $B$. bifidum and $B$. lactis fermented in media with 
glucose had a lower butyric acid value.

Interestingly the trends of production of propionic and butyric acids were similar for the tested strains, the highest producers of the both SCFAs were for $B$. lactis in media with salep powder, while and the lowest producers were $B$. longum in media with salep powder. These results agreed with Pessione et al. (2015) who studied characterization of potentially probiotic lactic acid bacteria isolated from olives and evaluation of short chain fatty acids production.

\section{Conclusion}

In this study, for the evaluation of bifidogenic effect by growth and metabolic activity achievements, growth curves were monitored by optical density assessment, and bacterial metabolism was assessed by $\mathrm{pH}$ measurement and as well as determination of short chain fatty acids production. Based on the results reported herein, salep powder may stimulate the growth of Bifidobacterium species. Enhancement of Bifidobacterium species growth and metabolism by the increase of lactic acid and short chain fatty acids production that it may be stated that salep powder has potential as "bifidus factor"

\section{Acknowledgements}

This study was funded in part by the Commission of Scientific Research Projects of Uludag University, Bursa, Turkey (QUAP (Z) 2013/50). This study is a part of Buse Usta's M.Sc. thesis submitted to the Uludag University, Institute of Natural Sciences.

\section{References}

Altundag, E., Sevgi, E., Kara, Ö., Sevgi, O., Tecimen, B.H., \& Bolat, I. (2012). Comparative Morphological, Anatomical and Habitat Studies on Dactylorhıza romana (seb.) Soó subsp. Romana and Dactylorhiza romana (seb.) Soó subsp. Georgica (klinge) soó ex renz \& taub. (Orchidaceae) in Turkey. Pakistan Journal of Botany, 44,143-152.

Anonymous (2012). Transgenomics Application Book: Chapter IV: HPLC Colums. USA, pp. 284-293.

Barczyńska, B., Śliżewska, K., Libudzisz, Z., Kapuśniak, K., \& Kapuśniak, J. (2015). Prebiotic Properties of Potato Starch Dextrins. Postepy Hig Med Dosw (online), 69,
1031-1041.

Barczynska, R., Slizewska, K., Jochyma, K., Kapusniaka, J., \& Libudzisz, Z. (2012). The Tartaric Acid-Modified EnzymeResistant Dextrin from Potato Starch As Potential Prebiotic. Journal of Functional Foods, 954-962.

Bernardeau, M., Vernoux, J.P., Henri-Dubernet, S., \& Guéguen, M. (2008). Safety Assessment of Dairy Microorganisms: the Lactobacillus Genus. International Journal of Food Microbiology, 126, 278-285.

Bindels, L.B., Delzenne, N.M., Cani, P.D., \& Walter, J. (2015). Towards a More Comprehensive Concept for Prebiotics. Gastroenterology \& Hepatology, 12,303-310.

Carlson, J.L., Erickson, J.M., Lloyd, B.B., \& Slavin, J.L. (2018). Health Effects and Sources of Prebiotic Dietary Fiber. Current Developments In Nutrtion, 2(3),1-8.

Champagne, C.P., Gardner, N.J., \& Roy, D. (2005). Challenges in the Addition of Probiotic Cultures to Foods. Critical Reviews in Food Science and Nutrition, 45(1), 61-84.

Connolly, M.L., Lovegrove, J.A., \& Tuohy, K.M. (2010). Konjac Glucomannan Hydrolysate Beneficially Modulates Bacterial Composition and Activity within the Faecal Microbiota. Journal of Functional Foods, 2, 219 224.

Fukuda, S., Toh, H., Hase, K., Oshima, K., Nakanishi, Y., Yoshimura, K., Tobe, T., Clarke, J.M., Topping, D.L., Suzuki, T., Taylor, T.D., Itoh, K., Kikuchi, J., Morita, H., Hattori, M., \& Ohno, H. (2011). Bifidobacteria can Protect from Enteropathogenic Infection Through Production of Acetate. Nature, 469, 543-547.

Fung, K.Y., Cosgrove, L., Lockett, T., Head, R. \& Topping, D.L. (2012). A review of the Potential Mechanisms for the Lowering of Colorectal Oncogenesis by Butyrate. British Journal of Nutrition, 108, 820-831.

García-Cayuela, T., Díez-Municio, M., Herrero, M., M. Martínez-Cuesta, M.C., Peláez, C., Requena, T., \& Moreno, F.J. (2014). Selective Fermentation of Potential Prebiotic Lactose-Derived Oligosaccharides by Probiotic Bacteria. International Dairy Journal, 38,11-15.

Gibson, G.R., \& Rastall, R.A. (2006). Prebiotics: Development \& Application. England: John Wiley \& Sons Ltd, $256 \mathrm{p}$.

Gomes A.M.P., \& Malcata F.X. (1999). Bifidobacterium spp. and Lactobacillus acidophilus: Biological, Biochemical, Technological and Therapeutical Properties Relevant for Use as Probiotics. Trends in Food Science and Technology, 10,39-157.

González-Rodríguez, I., Ruiz, L., Gueimonde, M., Margolles, A., \& Sanchez, B. (2013). Factors Involved in the Colonization and Survival of Bifidobacteria in the Gastrointestinal Tract. FEMS Microbiology Letters, 340,1-10.

Harmayani, E., Aprilia, V., \& Marsonoa, Y. (2014). Characterization of Glucomannan from Amorphophallus oncophyllus and its Prebiotic Activity in vivo. Carbohydrate Polymers, 112, 475-479.

Hongpattarakerea, T., Cherntonga, N., Wichienchotb, S., Kolidac, S., \& Rastall. R.A. (2012). In vitro Prebiotic Evaluation of Exopolysaccharides Produced by Marine Isolated Lactic Acid Bacteria. Carbohydrate Polymers, 87, 846- 852 .

Jagdale, S.P., Shimpi, S., \& Chachad, D. (2009). Pharmacological Studies of 'Salep'. Journal of Herbal Medicine and Toxicology, 3(1),153-156. 
Jahromi, H.K., Pourahmad, M., Abedi, H.A., Karimi, M., \& Jahromi, Z.K. (2018). Protective Effects of Salep against Isoniazid Liver Toxicity in Wistar Rats. Journal of Traditional and Complementary Medicine, 8,239-243.

Kaplan, H., \& Hutkins, W.R. (2000). Fermentation of Fructooligosaccharides by Lactic Acid Bacteria and Bifidobacteria. Applied Environmental Microbiology, 6, 2682-2684.

Keithley, J., \& Swanson, B. (2005). Glucomannan and Obesity: A Critical Review. Alternative Therapies, 11(6),30-34.

Kerry, R.G., Patra, J.K., Gouda, S., Park, Y., Shin, H-S., \& Das, G. (2018). Benefaction of Probiotics for Human Health: A Review. Journal of Food and Drug Analysis, 26(3),1-13.

Markowiak, P., \& Śliżewska, K. (2017). Effects of Probiotics, Prebiotics, and Synbiotics on Human Health. Nutrients, 9(9), 1-30.

McNabney, S.M., \& Henagan, T.M. (2017). Short Chain Fatty Acids in the Colon and Peripheral Tissues: A Focus on Butyrate, Colon Cancer, Obesity and Insulin Resistance. Nutrients, 9(12), 1-28.

Modler, H.W. (1994). Bifidogenic Factors- Sources, Metabolism and Applications. International Dairy Journal, 4(5), 383-407.

Morrison, D.J., \& Preston, T. (2016). Formation of Short Chain Fatty Acids by the Gut Microbiota and their Impact on Human Metabolism. Gut Microbes, 7, 189200.

Muller, W.S., Arcidiacono, S., Liebowitz, A., Racicot, K., Stenhouse, P., \& Soares, J. (2012). Growth Studies of Probiotic Bacteria On Short Chain Glucomannan, A Potential Prebiotic Substrate (Technical Report). U.S. Army Natick Soldier Research, Development and Engineering Center Natick, Massachusetts, 18 p.

Mumcu, S.A., \& Temiz, A. (2014). Effects of Prebiotics on Growth and Acidifying Activity of Probiotic Bacteria. Gıda, 39, 71-77.

Onakpoya, I., Posadzki, P., \& Ernst, E. (2014). The Efficacy of Glucomannan Supplementation in Overweight and Obesity: A Systematic Review and Meta-Analysis of Randomized Clinical Trials. Journal of the American College of Nutrition, 33, 70-78.

Pan, X., Chen, F., Wu, T., Tang, H., \& Zhao, Z. (2009). Prebiotic Oligosaccharides Change the Concentrations of Short-Chain Fatty Acids and the Microbial Population of Mouse Bowel. Journal of Zhejiang University. Science B, 10(4), 258-263.

Pessione, A., Lo Bianco, G., Mangiapane, E., Cirrincione, S., \& Pessione, E. (2015). Characterization of Potentially Probiotic Lactic Acid Bacteria Isolated from Olives: Evaluation of Short Chain Fatty Acids Production and Analysis of the Extracellular Proteome. Food Research International, 67, 247-254.
Pourahmad, M., Jahromi, K.H., \& Jahromi, K.Z. (2015). Protective Effect of Salep on Liver. Hepatitis Monthly, 5(4), e28137.

Rios-Covian, D., Arboleya, S., Hernandez-Barranco, A.M., Alvarez-Buylla, J.R., Ruas-Madiedo, P., Gueimonde, M., \& de los Reyes-Gavilan, C.G. (2013). Interactions between Bifidobacterium and Bacteroides Species in Cofermentations are Affected by Carbon Sources, Including Exopolysaccharides Produced by Bifidobacteria. Applied and Environmental Microbiology, 79 (23), 7518-7524.

Shigwedha, N., Hal, P. H-V., Jia, L., Sichel, L., \& Zhang, S. (2016). Promoting Health, Probiotics and Prebiotics in Human Nutrition and Health: Prebiotics: Metabolism and Symbiotic Synergy with Probiotics in Promoting Health. UK: IntechOpen, pp. 41-57.

Shokryazdana, P., Jahromia, M.F., Lianga, J.B., \& Hoc, Y.W. (2017). Probiotics: From Isolation to Application. Journal of the American College of Nutrition, 8(36), 666-676.

Sousa, S., Pinto, J., Pereira, C., Malcata, F.X., Pacheco, M.T.B., Gomes, A.M., \& Pintado, M. (2015). In vitro Evaluation of Yacon (Smallanthus sonchifolius) Tuber Flour Prebiotic Potential. Food and Bioproducts Processing, 95, 96-105.

Staiano, A., Simeone, D., Giudice, E. D., Miele, E., Tozzi, A., \& Toraldo, C. (2000). Effect of the Dietary Fiber Glucomannan on Chronic Constipation in Neurologically Impaired Children. The Journal of Pediatrics, 41-45.

Tester, R., \& Al-Ghazzewi, F. (2017). Glucomannans and Nutrition. Food Hydrocolloids, 68, 246-254.

Underwood, M.A, German, J.B., Lebrilla, C.B., \& Mills, D.A. (2015). Bifidobacterium longum subspecies infantis: Champion Colonizer of the Infant Gut. Pediatric Research, 77, 229-235.

Voragen, A.G.J. (1998). Technological Aspects of Functional Food-Related Carbonhydrate. Trends in Food Science and Technology, 9, 328.

Wang, J., Suna, B., Caoa, Y., \& Wanga, C. (2010). In vitro Fermentation of Xylooligosaccharides from Wheat Bran Insoluble Dietary Fiber by Bifidobacteria. Carbohydrate Polymers, 82, 419-423.

Wong, J.M, de souza, R., Kendall, C.W., Emam, A., \& Jenkins, D.J. (2006). Colonic Health: Fermentation and Short Chain Fatty Acids. Journal of Clinical Gastroenterology, 40(3), 235-243.

Zoumpopoulou, G., Kazou, M., Alexandraki, V., Angelopoulou, A., Papadimitriou, K., Pot, B., \& Tsakalidou, E. (2018). Probiotics and Prebiotics in Animal Health and Food Safety: Probiotics and Prebiotics: An Overview on Recent Trends. Cham, Switzerland: Springer International Publishing AG, pp. 1-34. 